\title{
ÂSIK TARZI YER İLE GÖK DESTANLARININ İCRÂ BAĞLAMINDA İŞLEVSELLİĞİ ÜZERINNE BİR DEĞERLENDİRME
}

\author{
AN EVALUATION ON MINSTREL STYLE EARTH AND SKY \\ DESTANS ACCORDING TO THEIR FUNCTIONALITY BY THE \\ CONTEXT OF PERFORMANCE
}

Erhan ÇAPRAZ*

\begin{abstract}
$\ddot{O} z$
Yer ve gök, Türk kozmogonisinde dikotomik tasavvurun temel unsurlarını teşkil etmektedir. Bu tasavvurun -tespit edebildiğimiz kadarıyla- ilk örneklerine XVII. yüzyılda rastladı̆̆ımız âş̧ı tarzı yer ile gök destanlarında da "tipikleştirilerek" aktarıldı̆̆ını görmekteyiz. Bu tipikleştirmede doğal olarak İslâmiyet'in getirmiş olduğu inanış ve değerler ön plandadır. Diğer taraftan destanlarda "münazara"nın egemen olması destanların icrâ bağlamında daha da işlevsellik kazanmasını sağlamıştır. Yani tarafların yer ile göğün teşkil ettiği diyaloğa dayalı anlatım tarzı, Türkler açısından bugün de geçerli olan mücadelenin (savaş) kodların da bünyesinde barındırmaktadır. Kanatimizce referans alınan bağlamını savaşların teşkil ettiğgi bu destanlar, âşıkların icrâlarıyla, yani dinleyiciyle kurulan yüz yüze iletişime bağhl gerçekleşen fasıllar sayesinde önemli işlevleri yerine getirmiştir. Öncelikle, destanlarda yaşam döngüsünün süreklilĭğini temsil eden bahar-kış, yer-gök gibi figürler, insanların dirilişe (ahiret) olan bağhllıklarının zinde kalmasını sağlamıştır. Ayrıca bu figürler içte ve dışta bir bütünlük durumu yaratarak ulusal bilincin de tesisini kolaylaştırmıştır. Diğer taraftan destanlar, dinî ve ahlâkî değerleri güncelleyerek insanların eğitimine dönük informal bir eğitim kanalı açarken aynı zamanda gerileme dönemiyle birlikte cephede sürekli ihtiyaç duyulan insan gücünün iman gücüyle bütünleşmesini de tesis etmiştir. Dolayısıyla yazıda mevcut yer ile gök destanlarından hareketle bu bütünleşmenin kodları çözümlenmeye çalışılmıştır.
\end{abstract}

Anahtar Kelimeler

Âşık tarzı yer ile gök destanları, münazara, mücadele (savaş), icrâ bă̆lamı, yer ve gök.

\section{Abstract}

Earth and sky are two main elements of dichotomic thought in Turkish cosmogony. This thought was transferred/carried by typical performances of minstrels' earth and sky poems which are from XVII.th century (as we can determine). As a matter of course in these typical performances, the beliefs and values come from Islam are on the foreground. On the other hand prevalence of 'debate' bring functionality to performing minstrel type destans (poems). Expression based on dialogue (its debators are earth and sky), has the codes of struggle (war) which still has validity in Turks life, in itself. From our view, these poems' context come from wars. These destans have very important functions by minstrel fasil's and in these fasil's they are performed face to face by minstrel to an audience. First of all figures like spring-winter, earth-sky which are symbolizing the life cycle, also symbolizes

\footnotetext{
* Dr. Öğr. Üyesi, Nevşehir Hacı Bektaş Veli Üniversitesi Fen-Edebiyat Fakültesi Türk Halk Bilimi Bölümü. E-posta:
} erhancapraz@nevsehir.edu.tr. ORCID ID: 0000-0001-8705-4981 
dependence of human's resurrection (afterdeath) idea. In addition to this, these figures creates a integrity situation inside and outside, so building/establishing national consciousness become easier. On the other hand, these destans updates the religional and moral values, so people educated in an informal way. This informal way also has used during war times while requiring human power and their faith power. By this way, human (soldiers) reunited its faith power. In this study this reunion's codes will be analyzed according to earth and sky destans.

Keywords

Minstrel style earth and sky destans, debate, struggle (war), context of performance, earth and sky. 
"Toplumlar öz imgelerini hayali olarak oluştururlar ve yarattıkları hatırlama kültürü ile bu imgeyi kuşaktan kuşağa iletirler"

Jan Assmann

\section{Giriş}

Âşık tarzı şiir geleneği içerisinde destanlar önemli bir yere sahiptir. Tespit edebildiğimiz kadarıyla XVII. yüzyıldan itibaren karşımıza çıkan "yer ile gök destanları"nın da bu gelenek içerisinde çok önemli bir "rol"e ve "işlev"e sahip olduğu görülmektedir. ${ }^{1}$ Dolayısıyla yazımızda âşık tarzı yer ile gök destanlarının icrâ bağlamında yerine getirdiği bazı işlevler üzerinde durulacaktır. Tabii öncelikle bu tarz destanların edebî geleneğimiz içerisindeki mahiyetinin ortaya konması gerekmektedir. Zira destanların icrâ bağlamında yüklendikleri işlevleri yeterince anlayabilmek için bunların edebî gelenek içerisinde yerinin, yani türlü yönleri ile özelliklerinin belirlenmesi büyük önem taşımaktadır. Sonrasında ise mevcut yer ile gök destanları üzerinden bir incelemeye ve değerlendirmeye girişilecektir.

Yer ile gök destanları, Türk edebiyatında, "münazara" geleneği içerisinde değerlendirilmektedir (Köksal 2006: 581; Yücel 2000: 280). Münazara, birbiriyle ilgili, çoğu kez de karşıt iki ya da daha çok nesne veya kavramın kişileştirilerek taraflardan her birinin kendisinin üstünlüğünü, karşısında bulunanın ise yanlışlıklarını, zayıflıklarını ortaya dökmek amacıyla hâl dilince konuşturulması yoluyla oluşan bir yazı türüdür (Tezcan 1980: 49). Münazaralar, "kahramanları (tartışmanın tarafları)" bakımından beş grupta değerlendirilmektedir: a) "Kahramanları insan olan münazaralar": Rind- zâhid, tabipmüneccim, zengin-fakir, kız-oğlan, evli bekâr, bedevî-şehirli gibi. b) "Kahramanları hayvan olan münazaralar": Papağan-karga, kedi-fare gibi. c) "Kahramanları cansız varlık olan alegorik mahiyetteki münazaralar": Çiçekler (gül-nergis, yasemin menekşe gibi.), mevsimler (yaz-kış, yaz-bahar gibi.), keyif verici maddeler (esrar-şarap, tütün-kahve gibi.), silâhlar (ok-yay, kılıçmızrak gibi.), yiyecekler (peynir-ekmek, hurma-üzüm gibi.), kıymetli taşlar (inci-mercan-la'lyâkut), şehirler (Mekke-Medine, Bağdat-İsfahan gibi.), türlü eşyalar (gûy u çevgân gibi.), çalg1 aletleri (çeng-kopuz, tambur-ud gibi.). d) "Mücerred kavramların münazarları": Devlet-akıl, akıl-aşk, gençlik-ihtiyarlık, hiddet-af, ümit-yeis gibi. e) "Değişik unsurların münazaraları": Kalem-gönül, kalem-kılıç, su-hava, deniz-katre, dil-ağız, beyaz-siyah, oruç-bayram, zülf-tarak gibi (Köksal 2006: 580).

\footnotetext{
Tespit edebildiğimiz kadarıyla bugün elimizde dokuz yer ile gök destanı bulunmaktadır. Bunlardan üçü XVII. yüzyılda yaşamış Âşık Ömer (Karasoy-Yavuz 2015: 355-356), Gevherî (Elçin 1998: 64) ve Kayıkçı Kul Mustafa'ya (Mecmû'a-i Eş‘̂̂r [yz.] 06 Mil Yz A 4592: 48a-50b) aittir. Diğer beş destan ise XIX. yüzyılda yaşamış Konyalı Âşık Şem ‘̂̂ (Cönk [yz.] 06 Mil Yz Cönk 64: 14a-15b; Cönk [yz.] 06 Mil Yz Cönk 269: 23a-25b), Na ‘tî (Cönk [yz.] 06 Mil Yz Cönk 50: 9b-12b), Zileli Tâlibî (AŞE XXVI: 741; Esen 1991: 212-214; Yardımcı 1989: 40-42; Artun 2009: 36-46), Sâdî (Akyüz 1960: 2173) ve Ermeni Aşug Nâdirî́ye (AŞE III: 165) aittir. Nâtî mahlası altında aktarılan destanda mahlas destana sonradan eklenmiştir. Dolayısıyla destanın Âşık Şem 'î'ye ait olması muhtemeldir. Son destan ise 1963 yılında Saimbeyli halk şairi Mahmut Sunar tarafından kaleme alınarak bastırılmıştır (Sunar 1963). Fakat bu destanın da pek çok dörtlüğü, Âşık Şem ‘î’nin destanının çeşitlenmesidir. Dolayısıyla destanların sözlü kültür ortamında dinleyiciyle yüz yüze kurulan iletişime bağlı bir icrâ süreci yaşadığını söyleyebiliriz. Ayrıca mevcut destanların üçte birinin XVII. yüzyıla ait olması, daha eski devirlere ait bu tarz destanların varlığına bir referans olarak kabul edilebilir. Dolayısıyla Özkul Çobanoğlu'nun "diyaloğa dayalı anlatım” tarzından dolayı bu tip destanların "en eski tipi" oluşturduğuna dair görüşü (Çobanoğlu 2000: 189) bu noktada daha çok haklılık kazanmaktadır.
} 
Meserret Diriöz ise münazaralarda en çok tekrarlanan konuların başında "esrar", "şarap" ve "diğer keyif veren maddeler"in geldiğini, bunları ise "kılıç ve kalem", "bahar-kış ve diğer mevsimler" ve "yer ve gök"ün takip ettiğini belirtmektedir (1980: 22). Dolayısıyla münazara geleneği içerisinde yer ve gögüun, dolayısıyla yer ile gök destanlarının önemli bir yere sahip olduğunu söyleyebiliriz. Tabii Diriöz'ün bu tespitine bağlı olarak sosyal, askerî ve dinî yaşamın münazaraların teşekkülünde temsil kabiliyeti kazandığını da düşünebiliriz. Yani destanlarda, toplumsal yaşamda insanları cezbeden keyif verici maddelerin egemenliğini, kılıç ve kalem arasında gidip gelen askerî ve toplumsal döngüyü ve kanaatimizce bu döngünün sürekliliğini sağlayan, dolayısıyla insanlara daima yeniden dirilişi (ahiret) telkin eden bahar-kış ve yer-gök mücadelesini görmekteyiz. Osmanlı'da Galata meyhanelerini dışarıda tutarsak Yıldırım Bayezid döneminden itibaren içkinin hayli yaygınlaştığını, bu durumun da genel meyhaneler açılmasına neden olduğunu, yani meyhanelerin ve âb âlemlerinin de yükselişe geçmeye başladığını (Sevengil 2014: 22-23) söylersek herhâlde ne demek istediğimiz daha iyi anlaşılabilir.

Âşık tarzı şiir geleneği içerisinde ise yer ile gök destanları, "yer ile gök arasında tasavvurî olarak bir çekişmeyi konu edinen ve yer ile göğün karşılıklı olarak birbirlerine üstünlüklerini kabul ettirmek için çeşitli özelliklerini saydıkları" (Çobanoğlu 2000: 87) destan niteliği taşımaktadır. Çobanoğlu'nun tematik olarak "doğal güzelliklerle ilgili destanlar" içerisinde değerlendirdiği bu tarz destanlarda "çoğul icracı anlatım tekniği" kullanılmıştır. Yani destanlar, iki tarafın yer aldığı karşıtlığın diyaloğu şeklinde kurgulanmıştır. Bu "karşılıklı diyalog" sayesinde de farklı "bakış açıları" yansıtılmış ve mevzuda "en tipik kabul edilen özellikler" ele alınmıştır (Çobanoğlu 2000: 183-184).

Hilmi Ziya Ülken, yer ile gök destanlarında da görüldüğü üzere destanları sadece "harp tasvirlerinden" ve "kılıç şakırtılarından" ibaret görmenin "büyük bir hata" olduğunu belirtmektedir. Ona göre aslolan "eserin ruhu"na ulaşmaktır. Bu ise destanın "ait olduğu milletin örf ve aklıselimindeki hususiyette" bulunmaktadır (2011: 66-67). Ayrıca Ülken'e göre destanlar kaynağını dinî kozmogoniden almıştır. Fakat bu alâka, onları "timsal" kabul ettiğimiz andan itibaren azalmaktadır (2011: 66-67). Nitekim M. Fuad Köprülü de Türklerin başka dinlere girmesiyle birlikte, eski inanışa ait kabullerin "millî birer örf ve âdet hükmüne gir[diğini]" belirtmektedir (2003: 39). Ayrıca Köprülü, İkdam' da âşık tarzı destanlar üzerine kaleme aldığ1 yazısında destanları, tarihî sürece bağlı olarak "millî bir mahsul" niteliği taşıyan "târihî destanlar", "dinî ve mezhebî mâhiyeti hâiz destan" ve "mizâhî yahut hicv-âmiz mâhiyeti hâiz"şeklinde sıralayarak bir taraftan destan geleneğinimizdeki sürekliliği ortaya koyarken diğer taraftan Ülken'in bahsettiği "dinî kozmogoniden" kopuşu da destanları sinıflayarak göstermeye çalışmıştır (1914a).

Bu bağlamda yer ile gök destanlarına baktığımız zaman, destanlarda "yer" ve "gök" şeklinde "kurmaca kahramanlarla temsil edilen iki tarafın" (Çobanoğlu 2000: 183) aslında Türklerde "Gök ile Yer-Su dikotomisi" (Esin 2001: 19) adı verilen kozmolojik tasavvurun da temel unsurları oldukları görülmektedir. Dolayısıyla yer ile gök destanlarının ibdâ ve icrâ sürecinin 'icrâ bağlamı' bakımından da köklü bir geçmişe/geleneğe sahip olduğu düşünülebilir. Zira Köprülü'nün aktardığı bilgilere göre Türklerde "sema" ve "yer" "iki dinî umde"yi teşkil etmekte olup Türkler bunlar için senede bir kez dinî merasim yapmışlardır. (2003: 39). Ayrıca Türklerin eski inanışına göre yeryüzünde "yüksek dağlarda, nehir menbalarında, ormanlıklarda" bulunan "Yer-Sub: Yer-Su" adında hayırsever ruhlar vardır. Bulundukları yerlerden geçilirken bu ruhlara kurban takdim edilmektedir. Tüm bu "dinî işler" ise "Kam"lar tarafından yürütülmüştür (Köprülü 2003: 39). Dolayısıyla tamamen dinî bir niteliğe sahip bu icrâ bağlamının daha sonraki süreçte ortaya çıkan, yer ile gök destanlarının icrâsını da içine 
alan icrâ bağlamları için bir anlamda "hatırlama kültürü"ne (Assmann 2015: 25) dönüştüğü düşünülebilir.

Yir ilen gök beste durmuş yarimüş

Yir şükr ider her hasilet bendedür

Gök demiş ki ber-hevayım yücede

Gök şükr ider her usulet bendedür_Kayıkçı Kul Mustafa (Mecmû'a-i Eş‘âr [yz.] 06 Mil Yz A 4592: 48a).

Yukarıdaki dörtlükte yer ile gök birbirine oldukça bağlı birer sevgili şeklinde kurgulanırken sanki bize Türklerin kozmolojik tasavvurundaki dikotomiyi hatırlatmaya çalışmaktadır.

Ayrıca âşıkların şiirlerinde yer alan arkaik ve mitolojik nitelikteki bazı imgeler aynı zamanda birer "geçmişi hatırlama nesnesi" (Connerton 1999: 40) olarak da kabul edilebilir.

Yir dedi bende[di]r yedi kat kapu

Saru öküzin dünyayı tutar soyu

Senin buludına ă̆dırır suyu

On yedi sultana bir nazar eyle_Âşık Şem‘î (Cönk [yz.] 06 Mil Yz Cönk 64: 14a).

Yer dedi benliği edersin her bar

Elestü bezminde tekrar be tekrar

Sarı öküzü geç balı̆̆a kadar

İns ü cin şah-ı devlet benimdir_Sâdî (Akyüz 1960: 2173).

Yukarıdaki dörtlüklerde yer alan dünyanın kozmik öküzün boynuzu üzerinde durduğu, öküzün de altında su ve hava bulunan bir balığın üzerinde bulunduğuna dair (Boratav 2012: 94) zoomorfik imalar, destanların konusu gereği Türk mitolojisine dönük önemli bağlantı noktaları şeklinde de değerlendirilebilir.

Çobanoğlu'nun aktardığı bilgilere göre bu tarz destanlarda diyaloğu gerçekleştiren "kurmaca temsilcilerin" "en tipik" özellikleri ele alınır. Yani destanlar, sosyo-kültürel bağlamda "tipik olanı" ve farklı olanı da "tipikleştirmek" suretiyle ele alıp işlemektedir (Çobanoğlu 2000: 184). Dolayısıyla yer ile gök destanları, Türklerin "Gök ile Yer-Su dikotomisi" adı verilen kozmolojik tasavvurunun yeni bir dinî ve kültürel atmosferde 'tipikleştirilmesi' şeklinde de düşünülebilir. Zira Joseph Campbell'ın aktardığı bilgilere göre "mitin mantığı, kahramanları ve yararları modern zamanlara kadar canlı kalmaktadır" (2013: 14). Tabii bu tipikleştirmede, özellikleri tayin eden temel unsurun İslâmiyet'e ait değer ve inanışlar olduğunu da ifade etmemiz gerekmektedir. Nitekim yukarıdaki ikinci dörtlükte "Bezm-i Elest"e yapılan vurgu, bir taraftan temel belirleyici unsurun İslâmiyet olduğunu açıkça ortaya koyarken diğer taraftan tipikleştirmenin yeni başlangıç noktasının İslâmiyet'in getirmiş olduğu anlayış ve değerler olduğunu ima eder vaziyettedir.

Bu Gevherî der ki geç maceradan

Hak'tır bizim cümlemizi yaradan

Yetmiş iki millet geçti aradan

Bir gün olur onlar da gelir divana_Gevherî (Elçin 1998: 64).

Yer söyledi aç gözünü bak bana 
Bende olan sende var mi dursana

Bende yatar cihan serveri hâlâ

Öyle devlet benim ihsan benimdir_ Âşsk Ömer (Karasoy-Yavuz 2015: 356).

Gök demiş ki benden indi dört (yüz) suhufı

Yalan değil her birisi hep sahi

Zebur Tevrat Incil Kur'an bir dahi

Hak kelamı dört kitabet bendedür

Yir demiş ki bende kurulur tamu

Girmek değil cümle hakkım meramu

Zebaniler mamur itmez varanu

Yer yüzünde kamu zulmet bendedür_Kayıkçı Kul Mustafa (Mecmû‘a-i Eş‘âr [yz.] 06 Mil Yz A 4592: 49a).

Gök der ki açıktır dergah-ı izzet

Bi-hadd [ü] bi-payan derya-ı rahmet

Ferişteler keuser hem sekiz cennet

Rıdvan-ı kasr huri gılman bendedir_Tâlibî (AŞE XXVI: 741).

Gök söyledi bize olmuş himayet

Âkıbet iderim sana himayet

Çok hur ile gilman buldu inayet

$B a^{\prime} z-\imath$ rıdvan ile cennet bendedür_ Nâdirî (AŞE III: 165).

Yukarıdaki dörtlüklerde yere ve göğe bağlı olarak aktarılan Hak, Hz. Peygamber, suhuf, Zebur, Tevrat, İncil, Kur'an, cennet, rıdvan, kevser ve cehennem gibi ulvî değerler, bir taraftan yere ve göğe bağlı tipikleştirmenin dinî açıdan dinleyici nezdindeki değerini daha da yüceltirken diğer taraftan icrânın (destan) "inananlar zümresi" üzerinde tesirini de kalıcı hâle getirmiş olmalıdır.

Diğer taraftan destanların "anlatım tutumu"nun (eda) da dinleyici nezdinde oldukça işlevsel olduğunu belirtmemiz gerekmektedir. Zira destanların "toplumsal dokuda" "işlevlerini" eda, yani konuyu ele alış tarzı belirlemektedir (Çobanoğlu 2000: 90-91). Dolayısıyla âşıklar da destanlarda ele aldıkları konuyu, "toplumun yapısını göz önünde bulundurarak, destanların toplumda görmesini istedikleri iş veya uyandırmak istedikleri duygu ve düşüncelere uygun düşen söz konusu kalıplaşmış temayüller, anlatım tutumları veya edalara göre oluşturmaktadırlar" (Çobanoğlu 2000: 91).

Bu bağlamda yer ile gök destanlarına baktığımızda destanlarda "bilgilendirmeye yönelik işleyiş"in (Çobanoğlu 2000: 100) etkili olduğunu söyleyebiliriz:

Yer söyledi türabımız denk verir

Seher vakti âlemlerin reng verir

Her bahçede yüz bin çiçek reng verir

Bî-gamdan kurtarır gülşan benimdir_Âş̧ı Ömer (Karasoy-Yavuz 2015: 355).

Gök dedi cümlenin sahibi Halil

Vakt ü zaman olur gör hükmü nazil 
Emr edüp çalınca suru İsrafil

Bilürüm ol zaman töhmet benimdir_Sâdî (Akyüz 1960: 2173).

Yukarıdaki dörtlüklerde yer alan doğaya ve kıyamete ait imalar, bir taraftan insanların varlığa/varoluşa dair bilgilerini tazelerken diğer taraftan insanlara uhrevî hayat için dünyevî zamana ve zemine karşı duyarlı olmayı telkin etmektedir.

Fakat kanaatimizce destanlardaki bu işleyiş, "kamuoyu oluşturmaya yönelik kullanım" şeklinde de düşünülmelidir. Bunun için bazı destanlarda tebliğe dayalı telkinin öne çıkarılarak "öğüt vermeye yönelik işleyiş" (Çobanoğlu 2000: 103) de güdülmüştür. Dolayısıyla yer ile gök destanlarında Çobanoğlu'nun tespitleri içinde yer almayan "telkin/tebliğ etmeye yönelik bir işleyiş" de düşünülebilir.

Gök demiş ki ahdimizde duralum

Hakk'ın emretdiği işler görelüm

Hakk'ın dergâhına yüzler sürelüm

Azim Allâh her havfiyyet bendedür

Kul Mustafâ bir Hudâ'ya münnetim

Eyle bizi sen Muhammed ümmeti

Cümlemüze ihsan eyle cenneti

Kerem eyle Hak inayet sendedür_(Kul Mustafa; 06 Mil Yz A 2591).

Gök söyledi dinle şimdi kelamı

Anla bir remz ile sen de meramı

Bendedir on iki burcun tamamı

Evc-i felek çerh-i seher bendedir_ Nâdirî (AŞE III: 165).

Yukarıdaki dörtlüklerde âşığın tebliğe ve telkine dair çabası açıç̧a görülmektedir. Fakat ikinci dörtlükte geçen "Anla bir remz ile sen de meramı" dizesi destanda yere ve göğe bağlı olarak aktarılan özelliklerin sadece bir "remz"den ibaret görüldügüünu, aslında asıl murat edilenin ise bu remizlerin arkasındaki hakikate ulaşmak olduğunu ortaya koymaktadır.

Kısacası bu tutum Çobanoğlu'nun ortaya koyduğu "destanların fonksiyonları açısından özellikleri"ne de uygun düşmektedir. Ayrıca XIX. yüzyıla gelindiğinde âşıklar "Tavukpazarı Cemiyet-i Âşıkânesi" adı altında bir cemiyet kurmuşlar, bu cemiyete bağlı olarak dinleyicilerin "hissiyât-1 harpcûyâne ve dindârânesini" teşvik edecek destanlar, güfteler ve koşmalar okumak ve "halkın hissiyâtını tehyiç ve hükûmetin istediği cihete imâle et[mek]" suretiyle de devlet tarafından desteklenmişlerdir (Köprülü 1914b). Dolayısıyla belki başlangıçta isteğe bağlı gerçekleşen bu tutum, daha sonraki süreçte bir anlamda zorunluluğa da dönüşmüştür diyebiliriz.

\section{1. İcrâ Bağlamında Yer ile Gök Destanları}

Âşık tarzı destanlar, yaratılageldikleri tarihî süreç içerisinde "yapılış" ve "yayılış" ortam ve araçlarına göre sözlü, yazılı ve elektronik olmak üzere her üç kültür ortamının da yapı ve fonksiyonlarına bağlı olarak icrâ edilmiştir (Çobanoğlu 2000: 123-159). Fakat "destanların hangi kültür ortamında yaratılırsa yaratılsın dinleyiciye yönelik bir icrâ etrafında odaklanmış olarak yaratılmaları konuların seçiminden, işlenişindeki edaya ve birlikte icrâ edileceği ezgiye ve en önemlisi onların dış ve iç yapısı üzerinde kalıplaşmalara yol açmışıır" (Çobanoğlu 2000: 123). 
Dolayısıyla destanların esasında "dinleyiciye yönelik bir icrâ etrafında odaklanmış olarak yaratılmaları", sosyo-kültürel ortamda "icrâ bağlamı"nın önem ve işlevselliğini daha da artırmıştır.

Şüphesiz âşıkların sanatsal üretim sürecinde en önemli unsur icrâ bağlamıdır. Zira onların ibdâ ve icrâları teşekkülünü ve özgünlügünü icrâ bağlamında dinleyici çevresiyle kurdukları iletişime borçludur (Başgöz 1986: 49-137; Ong 2007: 58). Dolayısıyla sözel ortam yaratıcılığında "fasıl"lara dönük bir ibdâ ve icrâ anlayışına sahip olmaları âşıkları bir taraftan toplum içerisinde daha saygın bir konuma taşırken diğer taraftan "toplum hayatının yürümesi için yapılan eylemler"de (Yıldırım 2000: 36) daha "işlevsel" kılmıştır. Bu itibarla fasıllar, âşıkların bir ritüele bağlı olarak kimlik kazandıkları icrâ alanı olmanın ötesinde çok derin anlamlara sahiptir. $^{2}$

Genel olarak yer ile gök destanlarının da fasıllara, yani "katılımcı grupla yüz yüze kurulan iletişim"e (Arslan 2015: 3) dönük bir icrâ süreci yaşadığını söyleyebiliriz. Zira destanlarda da karşımıza çıkan "geçmişin imgeleri ve geçmişin anımsanan bilgileri törensel denilebilecek uygulayımlarla (performans) taşınıp sürdürülmektedir" (Connerton 1999: 10). Dolayısıyla destanların yaratılış eyleminin (dünya döngüsünün) simgesel olarak tekrarında oldukça işlevsel bir nitelik kazandığı söylenebilir. Ayrıca destanlarda karşımıza çıkan karşıtlık temeline dayalı "diyaloğa dayalı anlatım" tarzı da bu sürecin açık bir göstergesi olarak değerlendirilebilir. Zira Çobanoğlu'na göre bu tip destanlar, "muhtemelen" "en eski tipi" oluşturmakla beraber, hem icrâ hem de ibdâ bakımından âşığa büyük kolaylık sağlayarak metnin ezberlenip hatırda tutulmasını kolaylaştırmıştır (2000: 189). Dolayısıyla bu durum, bir taraftan bu tür destanların sözlü kültür ortamında ibdâ ve inşâd edildiğini açıkça ortaya koyarken diğer taraftan da destanların köklü bir geçmişe sahip olduğunu (Çapraz 2018a) da işaret etmektedir. Nitekim Divânu Lugâti't-Türk'te yer alan yaz ile kış arasındaki münazara (Elçin 1993: 234-235), bu tarzın Türk edebiyatında çok eskilere dayandığının bir kanıtıdır. ${ }^{3}$

Diğer taraftan grup katılımını içeren bu icrâ süreci, destanlardaki geçmişle ilgili imgeler üzerinden Connerton'un ifadesiyle "var olan toplumsal düzeni meşrulaştırmaya yaradığı da ifade edilebilir" (1999: 10-11).

Gök demiş ki ahdimizde duralum

Hakk'ın emrettiği işler görelüm

Hakk'ın dergâhına yüzler sürelüm

2 “Âşıkların icrâlarını sergiledikleri 'fasıl'ların içeriği, inanılan ve fakat ulaşılamaz geçmiş ile ânı ve geleceği içeren tematik bir örüntü özelliği göstermektedir. Mitolojik dönemden itibaren kültür ve inanç çevrelerinin temel anlam alanları ve kodlamaları bu tematik örüntünün dokusunu meydana getirir. Âşık fasılları aynı zamanda, törensel bir iletişim için planlanmış 'kültürel bellek biçimi' dir. Kültürel belleğin içeriğini oluşturan tematik yapıya ilişkin yazılı olmayan kuralların kalıplaştırdığı ritüelistik ve teatral bir icrâ düzenidir" (Arslan 2015: 2-3). Dolayısıyla "âşı̆̆ın kültürel belleğe ilişkin taşıyıcılık görevini yerine getirmesindeki hatırlama ortamının bu törensel fasıllarla kolaylaştığını söylemek mümkündür" (Arslan 2015: 3). Bu bağlamda "kültürel bellek taşıyıcıllğı açısından âşık, gelenek içinde ustalardan edindiği geçmişi hatırlamanın temel figürlerini, içine doğduğu toplumun bizatihi kökenine ve varlığına ilişkin dini, milli, sosyal ve kültürel kodlamalarını, ritüel sunuş özelliğine sahip icrâlar sırasında ve özellikle katılımcı grupla yüz yüze kurulan iletişim yoluyla aktarır ve zihinlere kaydeder" (Arslan 2015: 3). Bu sayede "belleğin dinamik kalmasına ve süreklilik kazanmasına katkı sağlar. Fakat bu aktarımlar sırasında bazen geleneksel ve inanılan figürler ile bireysel figürlerin iç içe geçtiğini de gözden uzak tutmamalıdır" (Arslan 2015: 3). Kısacası Türk sözel kültür geleneğinin "işlev" ve "kodları", Türkistan'dan Macar platosuna kadar uzanan geniş yayılım sahasında inşa ettiği bu "hafıza mekânları" sayesinde varlıklarını sürdürmesini bilmiştir (Üçüncü 2012: 207).

3 Bu tarzın Türk edebiyatında tebarüz etmesinde çok eskiden beri Türklerin içtimai yaşamında etkili olan "sağ kol" ve "sol kol" şeklindeki yapılanmanın doğrudan tesiri vardır. Bu hususta geniş bir değerlendirme için bk. Çapraz $2018 \mathrm{~b}$. 
Azim Allâh her havfryyet bendedür_Kul Mustafa (06 Mil Yz A 2591).

Bu bağlamda yukarıdaki dörtlükte yer alan "ahdimizde duralım”, "Hakk'ın emrettiği işler görelüm" ve "Hakk'ın dergâhına yüzler sürelüm" şeklindeki dinleyiciye dönük tebliğ niteliği taşıyan ögütler, meşru zemini daha da sağlamlaştırmaya yönelik çabanın bir tezahürü olarak da değerlendirilebilir.

Ayrıca bir anlamda 'ritüel sunuş özelliği' taşıyan destanlar (icrâlar) sayesinde insan kozmolojik uğraşa doğrudan katılmakta "kaostan düzene (kozmosa) geçişi içeren mitolojik anın yinelenmesi" (Assmann 2015: 104) yoluyla da kendisini "dünya zamanı yanılgısı"ndan (Connerton 1999: 69) kurtararak "geçmişe yeniden 'şimdiki zamanlık' kazandır[maktadır]" (Assmann 2015: 100). Kanaatimizce destanlarda bahar ile kış ve yer ile gök arasında vuku bulan mücadele sayesinde bu kozmolojik eylem sürekli tekrarlanarak "inancın taşınması" (Assmann 2015: 110) ve insanların "dirilişs"e (ahiret) olan inançlarının her zaman ve zeminde sürekliliği sağlanmaya çalışılmıştır (Eliade 1994: 70). Bu ise ahirete inanan insan kitlesi üzerinde destanların tesirini daha da artırmış olmalıdır. Zira Osmanlının gerileme dönemiyle birlikte içine girdiği canlı savaş atmosferi, yer ile gök destanları sayesinde de insanların dirilişe olan inancının her zaman ve zeminde niçin tesis edilmeye çalışıldığını da izah eder kanaatindeyiz. Yani yer ile göğün mücadelesini "dramatize" ederek (Çobanoğlu 2000: 183) anlatan bu destanlar bir taraftan insanlara yeniden dirilişi empoze ederken diğer taraftan cephede sürekli ihtiyaç duyulan insan gücünün iman gücüyle bütünleşmesini sağlamış olmalıdır.

Ayrıca tıpkı Türklerin kozmogonik dikotomisinde olduğu gibi yer ile göğün destanın sonunda savaşmayı/mücadeleyi bırakarak 'birleşme'si dinleyici kitle açısından "içte ve dışta bir bütünlük durumu" (Sandner 1970: 18) yaratmış olmalıdır. Dolayısıyla destanlar bir anlamda yaratılışa dair "eylemi canlandırma yönünü üstlenmiştir" (Assmann 2015: 24). Jann Assmann'a göre 'canlandırma işlemi' ise "kutsal metni yorumlama anlamina gelen bir tür güncelleştirmedir" (Assmann 2015: 24). Bu durum aslında âşık tarzı destanların "halk kültürünün değer hükümlerini muhtevi motifleriyle verdikleri mesajın işlevselliği"ne (Çobanoğlu 2000: 119) de uygun düşmektedir. Zira âşık tarzı destanlarda görüldüğü gibi yer ile gök destanlarında da "toplumda yerleşik değerlerin güncelleştirilerek tekrarı ve bu yolla toplumun kendini tasdiki esastır" (Çobanoğlu 2000: 119).

Tâlibî ârifçün sözle her bir an

Hakk'a zikret fikrin itsün izan

Muhabbet nushasin yazmışım irfan

Arzuhâl itmeğe nalan bendedir_Tâlibî (AŞE XXVI: 741).

Mahmud da Allah'in bir kemter kulu

Hakk'a özü bağh ş̧aşırmaz yolu

Yer ile gökten ayırmaz eli

Ey şaşkın Allah'a bir seyran eyle_Mahmud (Sunar 1963).

Bu Gevherî der ki geç maceradan

Hak'tır bizim cümlemizi yaradan

Yetmiş iki millet geçti aradan

Bir gün olur onlar da gelir divana_ Gevherî (Elçin 1998: 64).

Yukarıdaki dörtlüklerde toplumda her zaman geçerli olan değerler üzerinden, dinleyici 
kitlesininin imanını/inancını tazelemesi telkin edilmektedir. Her ne kadar ilk dörtlükte muhatap, âşığın kendisi gibi görünse de diğerlerine baktığımızda âşığın aslında doğrudan dinleyiciyi muhatap alıp irşada giriştiğini söyleyebiliriz.

Kısacası yer ile gök destanlarının ve destan icrâlarının, ortamında (bağlam), tıpkı ritüellerde olduğu gibi "sosyal hayat içinde yaşanan kalıplaşmış manalı küçük dram" (Günay 1995: 2) niteliği taşıdığı da düşünülebilir. ${ }^{4}$ Bu itibarla gerek Emile Durkheim'in gerekse W. Bascom'un ritüellerin ve folklorun toplum içerisinde yerine getirdiği "eğlendirme", "eğitme", "fertleri birleştirip toplumsal bağları güçlendirme", "değerlere destek verip canlandırma", "mutluluk duygusu verme", "kültürü onaylama" ve "kabul edilmiş davranış örüntülerini sürdürme" (Bascom 2014: 71-86; Günay 1995: 2) şeklindeki temel fonksiyonların destanların icrâsı ve icrâ ortamı için de geçerli olduğunu söyleyebiliriz. Yani yer ile gök destanlarının müşterek duygu, düşünce ve inanç dünyasına sahip dinleyici çevresinin bir taraftan hoşça vakit geçirmesini sağlarken diğer taraftan kültürün eğitim işlerini yüklendiğini; kültürün ve kurumların doğrulanıp onaylanmasıyla da toplumda kabul edilen davranış örüntülerini sürdürme işlemini yerine getirdiği ifade edilebilir (Bascom 2014: 80-81).

Bu bağlamda yer ile gök destanlarının icrâsı ve icrâ bağlamı, tıpkı "anma törenleri"nde olduğu gibi "geçmişte olup bitenin anımsandığı bir ân içer[en]" eylemler sayesinde 'ulusal bilincin' dinamik kalmasını sağlamıştır (Connerton 1999: 27).

Ritüele dönük eylemlerde karşımıza çıkan "şiirsel biçim" (Assman 2015: 65) de birlikteliğin sağlanmasında ve insanın dâhil olduğu "bağlayıcı yapı"5 (Assmann 2015: 23) ile bütünleşmesinde başlı başına etkili olmuştur. Dolayısıyla destanların Ferris'in tıpkı halk şarkılarında olduğunu belirttiği gibi insanın "kültürün bütünüyle olan ilişkisinde muhafaza edici (cohesive) bir element olarak rol oyna[dığını]" (Ferris 1997: 87) da kabul edebiliriz. Zira fasıllar gibi kolektif belleğe dönük yapılarda "birey hem bilinç, hem de bilinçaltı düzeyde kendi kültürünün kökleriyle teması sürdürebilmektedir" (Ferris 1997: 87). Bunun gerçekleşmesini sağlayan şey ise esas itibariyle Seeger'in "zaman birleştirici" (time-binding) diye tanımladığ süreçtir (Ferris 1997: 90). Ayrıca destanların ritüel sunuş niteliği taşıyan fasıllara dönük bir icrâ zeminine sahip olması bunların halk şarkılarına göre daha dinamik bir yapı içerisinde bu süreci gerçekleştirmesini sağlamıştır. Diğer taraftan destanlar, "birey ile onun kültürü arasında bir bağın kurulmasını mümkün kılarak çalışma, tören ve eğlence kalıplarının devamını [da] sağlamıştır" (Ferris 1997: 90).

4 Zira ritüeller, "toplu yapılan gösterilerdir. Katılanları canlandırır, kışkırtır, korur, yeniden şekillendirir. Kişiye kutsal semboller, olaylar karşısında nasıl davranılacağını öğretir. Törelerin nitelikleri, amaçları ne olursa olsun hepsinde fertleri bir araya getirmek, aralarındaki bağları yoğunlaştırmak, yakınlaştırmak, daha samimi olmalarını sağlayarak toplum şuuruna ulaştırmak gibi nitelikler müşterektir. Fertler birlik içinde toplumdaki yerlerini ve toplumla ilişkili duygularını ritüellerle yenilemiş olurlar" (Günay 1995: 2). Hiç şüphesiz ritüellerle sağlanan bu müşterek niteliklerin ve yenile/n/me işlemin âşık tarzı destanlar içerisinde özellikle yer ile gök destanları gibi inanca dayalı, mitik veya kozmogonik bir menşei haiz destanlarda gerçekleşmesi yüksek bir ihtimal dâhilindedir.

5 Assmann'a göre "her kültür bağlayıcı yapı olarak adlandırdığımız bir şey oluşturur. Bu yapı, hem sosyal boyutta hem de zaman boyutunda birliştirici ve bağlayıcıdır. Ortak deneyim, beklenti ve eylem mekânlarından bir 'sembolik anlam dünyası' yaratarak, birleştirici ve bağlayıcı gücüyle güven ve dayanak imkânı sağlayarak insanları birbirine bağlar. Kültürün bu yanı eski milletlerde 'adalet' kavramı altında işlenir. Bu yapı aynı zamanda, değerli deneyim ve anıları biçimlendirip canlı tutarak ilerleme hâlindeki şimdiki zamanın görüntülerini ve öykülerini katarak ve böylece ümit verip canlandırarak dünle bugünü birleştirir. Kültürün bu yanı tarihi anlatılara ve efsanelere dayanır. Kültürün iki yönü, yani kuralcı ve anlatısal, yönlendirici ve nakledici yönü, bireylere 'biz' deme imkânı veren kimlik ve aidiyet temellerini yaratır. Tek tek bireyleri böyle bir 'biz'de birleştiren, bir yandan ortak kurallar ve değerlere bağlılık, öte yandan ortak yaşanmış geçmişin anılarına dayanan, ortak bilgi ve kendini algılayış biçiminin oluşturduğu bağlayıcı yapıdır" (Assmann 2015: 23). 
Yer ile gök destanlarının icrâsıyla dinleyici kitlesine dinî ve ahlâkî nitelikte informal bir eğitim kanalı açıldığını da düşünebiliriz. Zira "sözlü kültür ortamında âşığın bulunduğu her ortam âşığın daha önce meydana getirdiği veya irticalen meydana getirebileceği kendine ait veya usta malı destanları icra edebileceği resmî ortam hüviyeti" (Çobanoğlu 2000: 201) taşımaktadır. Dolayısıyla destanlara bağlı olarak sosyo-kültürel bağlamda böyle bir eğitimin verilmesi mümkün olabilir.

Tabii yer ile gök destanlarının tüm bu icrâ sürecinde "anlatıcı/aktarıcı/sanatkâr" (Görkem 2009: 413-414) vasfına sahip 'âşılar'ın da rolü büyüktür. Kanaatimizce sözlü kültür ortamında irticâlen de ibdâ ve inşâdlarda bulunan âşıklara dair "Hak vergisi âşıklık inancı" (Çobanoğlu 2000: 200) da "resmî ortam" da açılan bu informal eğitim kanalının önem ve işlevselliğini daha da artırmış olmalıdır.

Konu genişliği yanında destanları diğer türlerden ayıran en önemli tarafı bunların kendilerine has özel ezgilerle icrâ edilmesidir (Köprülü 1914a; Bölükbaşı 2001a: 402; Bölükbaşı 2001b: 405). Dolayısıyla destanların kendilerine mahsus bir beste ile icrâ edilmesinin de sözlü kültür ortamında bir taraftan destan ibdâ ve icrâsını kolaylaştırırken diğer taraftan hitap ettiği dinleyici kitlesinde tıpkı Ferris'in halk şarkılarında olduğunu belirttiği gibi bir bütünleşmenin tesis edilmesini de sağladığı düşünülebilir. Zira Çobanoğlu'nun belirttiği üzere "doğal ortamlarında" bu ezgilerin "adeta sosyal yapıyı şekillendiren sosyal normlarla özdeşleşen göstergeler şeklinde kullanılmaları" (2000: 319) söz konusudur. Kısacası "ezgili söz" ve "müzik" sayesinde destanın kolayca meydana getirilerek dinleyici üzerinde daha derin tesirler bıraktığı ifade edilebilir (Çobanoğlu 2000: 318-319).

\section{Sonuç}

Yer ile gök, Türk edebiyatının münazara geleneği içerisinde en çok işlenen unsurların başında gelmektedir. Dolayısıyla bu ve benzeri unsurlar, toplumsal yaşamla doğrudan alakalı önemli bağlantı noktalarını teşkil etmektedir. Başlangıçta Türk kozmogonisinde dikotomik tasavvurun kaynağını teşkil eden yer ile gök, daha sonraki süreçte İslâmiyet'in de getirmiş olduğu inanış ve değerlerle tipikleştirilerek âşık tarzı yer ile gök destanlarının teşekkülünü de sağlamıştır. Nitekim tespit edebildiğimiz kadarıyla bu tarz destanların XVII. yüzyıldan XX. yüzyılın ortalarına kadar icrâ kabiliyeti kazanmış olması bunların gelenek içerisinde işlevselliğini açıkça ortaya koymaktadır.

Her zaman ve zeminde var oluşlarının mücadeleye (savaş) bağlı olduğu Türklerde bu tarzın ilk örneğinin Divânu Lugâti't-Türk'te yer alması esasında destanların icrâ bağlamında işlevselliğinin kodlarını da bünyesinde taşımaktadır. Yani bugün de yaşadığımız coğrafyada verdiğimiz mücadele (savaş), temsilî de olsa bahar ile kışın, yer ile göğün taraf olduğu destanlarda kodlanmıştır. Ayrıca yaşam döngüsünün sürekliliğini de temsil eden bahar-kış ve yer-gök, inancın bir gereği olarak insanların dirilişe olan bağlllıklarının zinde kalmasını sürekli teşvik ederek savaş zemininde ihtiyaç duyulan insan gücünün iman gücüyle bütünleşmesini de sağlamış olmalıdır.

Âşıkların fasıllara dönük icrâ anlayışına sahip olmaları bu anlayışın dinamik bir yapı içinde, yani dinleyici ile yüz yüze kurulan iletişime bağlı olarak aktarılmasını kolaylaştırmıştır. Dolayısıyla destanlar sayesinde dinleyici kitlesine dönük dinî ve ahlâkî nitelikte informal bir eğitim kanalı açılırken aslında ulusal bilincin de dinamik bir yapı içerisinde süreklilik kazanması sağlanmıştır. 


\section{Summary}

Epics has a significant place in the tradition of minstrel poetry. In these epics, earth and sky epics have more importance. Because earth and sky are the basic elements of the dichotomical conception in the Turkish cosmogony. the first examples of these epics are from XVII.th century. As far as we can see, it is seen that this dichotomy concept is typified and transferred in the epics of the earth and sky. But the beliefs and values that Islam naturally brings to this typification are the forefront.

At the same time, the presence of epics in the debate tradition has enabled them to become more functional in the performance context. The fact that most of the topics that are handled in the debate tradition, are about earth and sky epics, support this idea. The narration style based on the dialect which the sides of the epistle constituted with the earth and sky carries the codes of the struggle which the Turks gave throughout history. Of course, it is important that the context in which the epics are referenced constitutes wars. Therefore, we should say that these epics fulfill some important functions by the minstrels.

First of all, we must say that the process of informing, the epics are effective. Because the allusions about nature and doomsday in the epics convey information about existence. From the other side, they suggest to them to be sensitive to worldly things for the Hereafter. Therefore, we can say that there is a function in the epics to notify the public according to our opinion.

When we look at the functions that the earth and sky epics bear in the execution context, we have first of all ensured that these are carried into faith and that humans are always in touch with the eternal dependence of the Hereafter. Because the atmosphere of the lively battle that the Ottoman Empire entered into with the decline period is in fact a source of this effort. In other words, these epics, which are narrated by the dramatization of the earth and sky, have gained a function for the supply of the human power needed on the other side while the people imposed afterlife on one side. In addition, epics have created a state of integrity both inside and outside and the social consensus has been established in each subject. In this context epics have been instrumental in being active in a dynamic structure of national consciousness.

E. Durkheim and W. Bascom's functions of rituels and folklore (f.e. entertaining, training, unifying individuals and strengthening social ties, supporting and reviving values, feeling happiness, approving culture and maintaining accepted behavior patterns) in the society are also applicable to the performance context of the epics. Therefore, it can be said that performing epics have opened an informal educational channel in religious and moral quality to the audience. Of course, in all these integration processes called J. Assmann's binding structure, the poetic form of the epics and their special musics have also been influential. 


\section{Kaynakça}

AKYÜZ, Hasan (1960), “Bir Cönk'ten: Yer ile Gök Destanı. Türk Folklor Araştırmaları”, 131: 2173.

ARSLAN, Mustafa (2015), "Kültürel Belleğin Uzman Taşıyıcıları Olarak Âşıklar”, Türk Dünyası Incelemeleri Dergisi, 15/1: 1-6.

ARTUN, Erman (2009), “Destan Söyleme Geleneğinde Âşık Talibi'nin Yeri”, Tarihi ve Kültürüyle Zile Sempozyumu Bildirileri, Zile: Zile Belediyesi Kültür Yay.: 36-46.

ASSMANN, Jann (2015), Kültürel Bellek, (çev. Ayşe Tekin), İstanbul: Ayrıntı Yay.

AŞE III: Ahmet Şükrü Esen Defterleri, 3 numaralı defter, Türkiye Ekonomik ve Toplumsal Tarih Vakfı: Pertev Naili Boratav Arşivi.

AŞE XXVI: Ahmet Şükrü Esen Defterleri, 26 numaralı defter, Türkiye Ekonomik ve Toplumsal Tarih Vakfı: Pertev Naili Boratav Arşivi.

BASCOM, William R. (2014), "Folklorun Dört İşlevi”, (çev. Ferya Çalış), Halk Biliminde Kuramlar ve Yaklaşımlar 2, (hzl. M. Öcal Oğuz, Selcan Gürçayır Teke), Ankara: Geleneksel Yay.: 71-87.

BAŞGÖZ, İlhan (1986), “Hikâye Anlatan Âşık ve Dinleyicisi”, Folklor Yazıları, İstanbul: Adam Yay.: 49-137.

BORATAV, P. Naili (2012), Türk Mitolojisi / Oğuzların - Anadolu, Azerbaycan ve Türkmenistan Türklerinin Mitolojisi, (çev. Recep Özbay), Ankara: BilgeSu Yay.

[BÖLÜKBAŞI], Rıza Tevfik (2001a), "Merdâne Türküler ve Destanlar", Rıza Tevfik'in Tekke ve Halk Edebiyatı İle İlgili Makaleleri, (hzl. Abdullah Uçman), İstanbul: Millı̂ Eğitim Bakanlığı Yay.: 398403.

[BÖLÜKBAŞI], Rıza Tevfik (2001b), “Destanlarımız”, Rıza Tevfik'in Tekke ve Halk Edebiyatı İle İlgili Makaleleri, (hzl. Abdullah Uçman), İstanbul: Millî Eğitim Bakanlığı Yay.: 404-409.

CAMPBELL, Joseph (2013), Kahramanın Sonsuz Yolculuğu, (çev. Sabri Gürses), İstanbul: Kabalcı Yay. CONNERTON, Paul (1999), Toplumlar Nasıl Anımsar?, (çev. Alâeddin Şenel), İstanbul: Ayrıntı Yay. Cönk, Millî Kütüphane, Millî Kütüphane Yazmalar Koleksiyonu, No: 06 Mil Yz Cönk 50, vr. 9b-12b.

Cönk, Millî Kütüphane, Millî Kütüphane Yazmalar Koleksiyonu, No: 06 Mil Yz Cönk 64, vr. 14a$15 b$.

Cönk, Millî Kütüphane, Millî Kütüphane Yazmalar Koleksiyonu, No: 06 Mil Yz Cönk 269, vr. 23a$25 b$.

ÇAPRAZ, Erhan (2018a), "Âşık Tarzı Yer ile Gök Destanlarının Kökeni Üzerine Bir İnceleme”, Selçuk Üniversitesi Edebiyat Fakültesi Dergisi (SEFAD), 39: 105-118.

ÇAPRAZ, Erhan (2018b), “'Mücadele'den 'Münazara'ya: Türk Edebiyatında Münazaranın Kaynağına Dair İçtimai Bir Bakış", İstanbul Üniversitesi Edebiyat Fakültesi Türk Dili ve Edebiyatı Dergisi (TUDED), 58: 21-41.

ÇOBANOĞLU, Özkul (2000), Âşık Tarzı Kültür Geleneği ve Destan Türü, Ankara: Akçağ Yay.

DİRIÖZ, Meserret (1980), “Türk Edebiyatında Münazâra”, Millî Kültür, C II (1): 20-22.

ELÇİN, Şükrü (1993), Halk Edebiyatına Giriş, Ankara: Akçă̆ Yay.

ELÇİN, Şükrü (1998), Gevherî Divânı, Ankara: Atatürk Kültür Merkezi Başkanlığı Yay.

ELİADE, Mircea (1994), Ebedi Dönüş Mitosu, (Çev.: Ü. Altuğ), Ankara: İmge Kitabevi Yay.

ESEN, A. Şükrü (1991), Anadolu Destanları, (hzl. P. N. Boratav). İstanbul: Kültür Bakanlığ1 Yay.

ESIN, Emel (2001), Türk Kozmolojisine Giriş, İstanbul: Kabalcı Yay.

FERRİS, William J. (1997), “Halk Şarkıları ve Kültür: Charles Seeger ve Alan Lomax”, (çev. F. Gülay Mirzaoğlu), Millî Folklor, 34: 87-93.

GÖRKEM, İsmail (2009), Dünden Bugüne 'Türk Sözel Edebiyatı': Değişim ve Dönüşüm, A. Ü. Türkiyat Araştırmaları Enstitüsü Dergisi, 39: 411-422.

GÜNAY, Umay (1995), “Ritüeller ve Hidrellez”, Millî Folklor, 26: 2-3.

KARASOY, Yakup - YAVUZ, Orhan (2015), Âşık Ömer Divanı, Konya: Konya Büyükşehir Belediyesi Kültür Yay.

[KÖPRÜLÜ] Köprülüzâde M. Fuad (1914a), “Destânlarımız”, İkdam, 31 Mart 1914.

[KÖPRÜLÜ] Köprülüzâde M. Fuad (1914b), “Saz Şâirleri 6- Âşık Teşkilatı ve Âşık Fasılları”, İkdam, 25 Nisan 1914.

KÖPRÜLÜ, M. Fuad (2003), Türk Edebiyatı Tarihi, Ankara: Akçă̆ Yay.

KÖKSAL, M. Fatih (2006), “Münazara (Türk Edebiyatı)”, Türkiye Diyanet Vakfı İslâm Ansiklopedisi, 
C. 31, İstanbul: Türkiye Diyanet Vakfı Yay.: 580-581.

Mecmû 'a-i Eş âr, Millî Kütüphane, Millî Kütüphane Yazmalar Koleksiyonu, No: 06 Mil Yz A 4592, vr. $48 \mathrm{a}-50 \mathrm{~b}$.

ONG, Walter J. (2007), Sözlü ve Yazılı Kültür / Sözün Teknolojileşmesi, (çev. Sema Postacıŏlu Banon), İstanbul: Metis Yay.

SANDNER, Donald F. (1970), "Analitik Psikoloji ve Şamanlık”, Kutsal Miras / Yılanın Biri Beni Şaman Yoluna Çă̆ırıyor, (çev. Nur Yener), İstanbul: Okyanus Yay.

SEVENGİL, Refik Ahmet (2014), İstanbul Nasıl Ĕ̆leniyordu?, İstanbul: Alfa Basım Yayım.

SUNAR, Mahmut (1963), Yerle Göğün Davası, Samsun: Örnek Matbaası.

TEZCAN, Nuran (1983), “Lâmi'î’’nin Gûy u Çevgân'ından İki Münazara”, Belleten, (1980-1981): 4963.

ÜÇÜNCÜ, Kemal, (2012), “Mehmed Esad Serezli'nin Kayıt ve Tanıklığıyla Serez Yöresi Türk Kültür Geleneği", Türkbilig, 24: 187-208.

ÜLKEN, H. Ziya (2017), “Türk Kozmogonisi”, Anadolu Kültürü Üzerine Makaleler, (hzl. G. Ülken), Ankara: Doğu Batı Yay.: 231-272.

YARDIMCI, Mehmet (1989), Zileli Âşık Tâlib̂̂, İstanbul: İnanç Yay.

YILDIRIM, Dursun (2000), “Türk Sözel Kültüründe Süreklilik <Osmanlı Hanedanlığ Cumhuriyete>", Türkbilig, 2000/1: 32-45.

YÜCEL, Ayşe (2000), “Türk Edebiyatında Münâzara ve Şenlik'in Münâzaraları”, Âşık Şenlik Sempozyumu Bildirileri, Ankara: Kültür Bakanlığı Yay.: 279-292. 